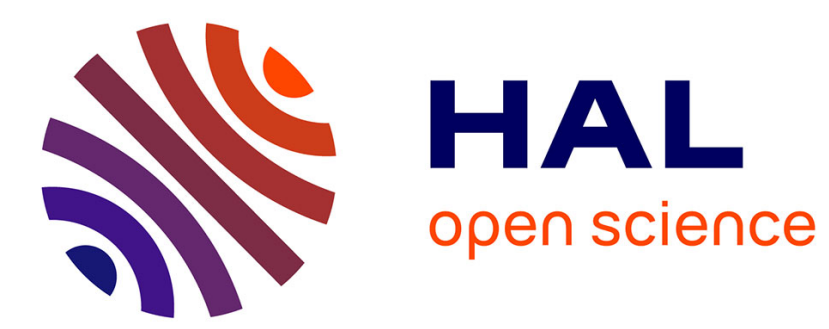

\title{
Stand-in as a performative repertoire of action Özge Derman
}

\section{To cite this version:}

Özge Derman. Stand-in as a performative repertoire of action. Turkish Studies, 2017, Conventional versus non-conventional political participation in Turkey: dimensions, means, and consequences, 18 (1), pp.182-208. 10.1080/14683849.2016.1273777 . hal-03024388

\section{HAL Id: hal-03024388 \\ https://hal.science/hal-03024388}

Submitted on 15 Jan 2021

HAL is a multi-disciplinary open access archive for the deposit and dissemination of scientific research documents, whether they are published or not. The documents may come from teaching and research institutions in France or abroad, or from public or private research centers.
L'archive ouverte pluridisciplinaire HAL, est destinée au dépôt et à la diffusion de documents scientifiques de niveau recherche, publiés ou non, émanant des établissements d'enseignement et de recherche français ou étrangers, des laboratoires publics ou privés. 


\title{
Stand-in as a Performative Repertoire of Action
}

\section{ÖZGE DERMAN}

Centre de Recherches sur les Arts et le Langage (CRAL), Ecole des Hautes Etudes en Sciences Sociales, 96 Boulevard Raspail 75006 Paris, France ozge.derman@ehess.fr ozgezderman@gmail.com

\begin{abstract}
Numerous rallies, gatherings and occupations in public squares of big cities have been emerging since 2010 all around the world as a new guideline to new social movements. These recent movements embrace a transformation in public spaces through interaction, shared experience and art so that a collective energy is generated within a given context and time. They therefore propose an alternative acting and living together in the light of the equality of all individuals involved. The recreation of this new active citizenship, both individually and collectively, is also highly connected with the appropriation of a performative repertoire of action within everyday life.

This paper focuses on the active, yet unorganized participation of Turkish citizens to the protestation and/or performance of the Standing Man all over Turkey. Standing still and silent offers thus a performative action, which has become collective through social networks. This unpredicted act has been a pioneer in terms of the transformation of a singular creative intervention to a collective performative action.
\end{abstract}

Keywords: Standing Man; Gezi Uprising; Artistic intervention; Performative action; Occupy. 


\section{Introduction}

Artistic and performative action in new Occupy movements carries significant weight thanks to the recreation of active citizenship under violent circumstances. The Gezi Uprising took place in Turkey in May and June 2013, subsequent to those Occupy movements all around the world. They therefore have similar characteristics such as the occupation of public spaces, shared experience, experimentation of alternative living and acting together, horizontal organization during resistance, the considerable use of social media and performative action and ultimately artistic intervention. Considering the immediacy and unpredictability of the latter, those movements including Gezi, embrace a transformation of political action repertoire ${ }^{1}$ as they all elicit a non-organized and spontaneous form of resistance. Therefore, Occupy movements reveal alternative forms of solidarity and creativity in the light of social and political contemporary issues.

The present paper mainly focuses on the protestation and/or performance of the Standing Man and the active, yet unorganized participation of Turkish citizens to this act all over Turkey. Following nineteen days of protest movement and the occupation of Gezi Park in Istanbul in May and June 2013, the country and the world witnessed a new form of protest action, that of a single man standing still and silent for eight hours in Taksim Square on June 17, 2013. An artist and performer Erdem Gündüz - a fact understood around the end of his act - stood without speaking and moving in that square beside the Gezi Park in order to protest police violence during the demonstrations. Soon afterwards, he was not the only one standing still.

Standing still and silent would, on the one hand, propose a nonviolent direct action related to political protest and, on the other hand, it would put forth a creative and performative action, which makes use of contemporary artistic repertoires. The intervention of the Standing Man thus represents a new way of artistic expression as well as political resistance. Such interpenetration of art and politics in the contemporary world indicates an era of creative tactical resistance starting from the protests against the WTO in Seattle in 1999. However, it would be hard to deny that there has been a significant inspiration from the Situationists and the happenings in the 1960 s as well as the political repertoire of nonviolent action of the Indian anticolonial resistance and the African-American Civil Rights Movement in the USA. 
In this regard, I would suggest that the nonviolent performative action and "stand-in" of the Standing Man not only exhibits a close relationship between art and politics, but it also incorporates the transformation of a singular and individual creative act into a collective performative intervention. Hence, it enriches both political and artistic repertories by utilizing a tactical small gesture of everyday life.

Since this act introduces an extensive concept that necessitates an exploration of interdisciplinary knowledge, this paper will firstly provide an overview of the theoretical framework of New Social Movements (NSMs), alter-globalization movements and active citizenship along with the description of Occupy movements and the Gezi Uprising. Then it will discuss the relationship between art and politics in accordance with the concept of performativity and its roots in political repertoire of action. Afterwards, the act of Standing Man will be described. The research reposes on a qualitative methodology, which puts forward the understanding of the principal actor's experience and the interpretations in the media. Accordingly, a comprehensive interview is conducted with the artist to understand his sensible and corporal experience and an investigation of mainstream and social media is made. Finally, the analysis of the paper through a hermeneutic-interpretative approach will be presented, supported with the theories of previous sections as well as the new theoretical guidance on which findings of the research will be built.

\section{Active Citizenship: from NSMs to Post-2010 Occupy Movements}

Since this article analyses the Gezi Uprising and the new forms of active citizenship as integral to the Occupy movements, it is indispensable to present a brief theoretical framework of NSM theory starting from the protests of 1968 and then moving on to the alter-globalization movements of 1990s. This historicization is fundamental in order to be able to comprehend the core concepts of current Occupy movements and their transformation, especially regarding the transition from post-industrial to global society.

NSM is developed from the idea that it represents a diversification from conventional social movements, which are identified principally by class conflict such as labor movements. In this respect, NSMs firstly refer to a new wave of protest action related to the rise of post-industrial society during the $1960 \mathrm{~s}$, and then they 
mark a considerable transformation concerning the participation of new actors and new groups. ${ }^{2}$ In general terms, NSMs represent decentralized forms of organization, alternative values or claims such as quest of identity or lifestyle issues and a transformation regarding the relationship to politics of the actors and groups. ${ }^{3}$

Touraine emphasizes the capacity of "self-production and self-transformation"4 of the actor within NSMs as they are "less sociopolitical and more sociocultural"5 such as women's movement and actions against the use of nuclear energy. Likewise, Melucci points out a shift "from the political form to a cultural ground" in relation with the transformation in the sphere of information. He stresses that the quest for identity, the body, the emotions, the daily experiences, that is to say the "individual" by discovering "the capacity to reject the dominant codes"7 becomes more of the core of those movements in which the system's overall logic is concurrently questioned. ${ }^{8}$ Regarding the new "political paradigm" analyzed by $\mathrm{Offe}^{9}$, the values such as "autonomy, identity and opposition to manipulation"10 is related to the new space of action representing "a space of noninstitutional politics", which seems to be a third universe of action alongside the private and institutional politics spheres. ${ }^{11}$ Within this new paradigm, he underlines the environmental, human rights, peace and feminist movements, which represent the demands "strongly universalistic or, to the contrary, highly particularistic." 12

Those movements articulated within the post-industrial society lead to a proliferation of non-governmental organizations (NGOs) since 1970s, however the "NGO boom"13 of the 1990s in several countries around the globe represents an intense institutionalization of those organizations. As a result of the transformation of the society through neoliberal globalization, NGOs are introduced as compensatory elements with the abdication of the state from its traditional role ${ }^{14}$ and the promoters of civil society. However, the debates around the NGO-ization reveal the two poles of those organizations: their utility for change as a development discourse to fill the gap of retreating states on the one hand, and on the other, their cooperation with the governments, multinational corporations and international organizations such as World Bank, which results in the depoliticization and danger for resistance. ${ }^{15}$ That latter point is critical, as several authors point out, that NGOs turn "confrontation into negotiation"16 since they became "a sort of buffer between (...) Empire and its subjects" 17 by entailing "national and global neo-liberalism's active promotion."18 
Within the NGO/INGO professionalization process, a new class of activist/lobbyists generates, a fact that consequently "pushes towards upward vertical participation and not downward horizontal participation." 19

Following a period of institutionalization of former actors and withdrawal of cultural actors into their identities in 1980s and 1990s, begins a new phase of mobilizations across the globe towards the end of 1990s: global movements. ${ }^{20}$ In this regard, Pleyers ${ }^{21}$ investigates those global justice movements, in other words alterglobalization movements, which constitute a cooperative global movement developed as an opposition to the negative effects of economic globalization. Firstly, the local and national mobilizations against neoliberalism such as Zapatista Movement in Mexico in 1994 emerged, which consequently became visible in global level with the Seattle Protests against World Trade Organization (WTO) Conference in 1999. With the initiation of civil society networks such as ATTAC, the gatherings in World Social Forums (WSF) starting from the $1^{\text {st }}$ WSF in Porto Alegre in 2001, in Florence in 2002 and Mumbai in 2004 and the mobilizations against WTO in Seattle, in Cancun and against G8 in Genoa, in Evian etc., the global justice movement extended geographically. ${ }^{22}$ G8, G20, World Bank, IMF and WTO have been the main targets of the global activists as these organizations represent the economic model of neoliberalism against which they rallied. Despite the global targets, those movements managed to combine, according to Wieviorka, the "requests for cultural recognition with demands for social justice and forms of behaviour contributing to the opening up of new political spaces." 23

Therefore, it is not surprising that the recent 'Occupy' or 'post-2010' mobilizations around the world give equally reference to social justice, dignity and democracy. ${ }^{24}$ Touraine equally points out "the dignity of human being" 25 as the core concept of these movements, which emerge as a continuation of Berkeley in the 1960s, later on in Tiananmen in 1989 and recently in Tunisia, in Cairo, in Chile in 2011. He describes all as 'ethico-democratic' movements through which the actors become "the creators of their history and destiny." 26 Even though the impact of globalization and social, cultural and political contexts are not identical all over the world, the recent mobilizations appear to "speak to one another."27

The Occupy movements that have taken place throughout the world since 2011 strongly embrace a transformation of political and social action in the public sphere. 
The rallies and occupations of public spaces directed against economic, political, social and/or cultural inequalities started off with the "Arab Spring" in December 2010, prompting a series of protests against authoritarian regimes in several Arab countries. Inspired by and along with those protests, the gatherings extended through European countries and the United States: in May 2011 the 'indignados' claimed their right to dignity, freedom and democracy in Madrid; in May 2010 and 2011 the antiausterity movement emerged in Athens due to the public debt crisis; in September 2011 the citizens occupied Zuccotti Park which is in the Wall Street financial district in New York and many other protests occurred in Asia and South America. Without underestimating the local specificities of each one of them, all those rallies reveal several common characteristics such as the democratic and horizontal organization of different interest groups, absence of a particular leader, presence of police violence, nonviolence of most of the demonstrators and considerable use of social networks. ${ }^{28}$ The encampment or occupation of public spaces constitutes the most evident commonality, which differentiates those from previous 'nomadic' alter-globalization movements. ${ }^{29}$ Moreover, as Hardt and Negri asserts, there exists a struggle for the common even though it is expressed by a variety of ways. For Pleyers, "the transformation of the individual's subjectivity (...) across fences and borders" ${ }^{\prime 30}$ appears to be an outcome through which people faced the fear and experienced their creativity. The actors shape thus their own trajectories, produce their own experiences, invent their own creativities along with their contribution to the collective action. ${ }^{31}$

Furthermore, the distinguished feature of the Occupy movements, or "networked social movements" 32 as Castells puts it, results from the considerable use of digital communication platforms in order to share information. The crucial transformation in current global movements takes place through the rise in the use of the Internet and wireless networks for communication. ${ }^{33}$ Social networking tools such as Twitter, Facebook and Youtube transformed the way those movements organized in relation with the physical face-to-face interaction during the occupations. ${ }^{34}$ The rapid diffusion of the information at national and international levels facilitates both the propagation of movements and specific themes in the movements through the use of hashtags (\#) on Twitter. 
The occupied public space and the digital space constitute an interactive and non-hierarchical sphere of action. ${ }^{35}$ According to Juris, besides determining emerging forms and structures, "networking technologies (...) shaped new political subjectivities based on the network as an emerging political and cultural ideal." 36 The social media constitutes thus a heterogeneous and open cultural sphere, which politicizes subjects in everyday life by which a less formal practice of citizenship comes into being. ${ }^{37}$ What is more, the linking of ideas and topics through hashtags could apparently bring people together 'offline' as it appeared during the initiation of every Occupy movement and also around specific actions throughout those demonstrations.

\section{The Gezi Uprising}

The Gezi Uprising in Turkey as a part of this global resistance wave ${ }^{38}$ portrays one of the local contexts in relation to the globally interconnected mobilizations. Depending on the circumstances under which every single protest took shape, motivations and demands unique to each of them existed as well. According to Yörük and Yüksel ${ }^{39}$, those movements could be divided into three categories. While the first one involves the Occupy Wall Street, Indignados and Greek protests representing anti-austerity and anti-liberal demands, the second category projects anti-authoritarian and prodemocratic protests such as the Arab Spring and the demonstrations in Russia and Hong Kong. The third one is characterized by inflation, policies of expansion and construction in countries such as Brazil and India. They suggest that the Gezi Uprising in Turkey does not fit the first category, just as Özatalay ${ }^{40}$ who also differentiates the motivations of Occupy Wall Street and the Gezi resistance. Moreover, it is not possible to frame the latter in classical class codes ${ }^{41}$, but rather the main trigger of Gezi seems to be political ${ }^{42}$. According to Tugal ${ }^{43}$, while the main trigger of protest in USA was the commodification of money, in Turkey it was that of nature and in Egypt, in Tunisia, in Brazil and in southeastern European countries it was the commodification of labor. In addition to that, he asserts that in Turkish and Brazilian cases the leading aspect is urban right issues and he outlines the proximity of Greek and Spanish uprisings as they present a discontent towards the corruption within the state bodies. There certainly exists a distinction between national and local 
conditions and demands, nevertheless a frustration towards global structures were articulated on broader perspective as it is previously discussed in this article.

As a part of the protest wave mentioned above, the Gezi Uprising in Istanbul represents resistance against the ongoing repression of the Turkish government whose decisions acutely affect the lifestyle of several citizens ${ }^{44}$ even though the protests initiated as an environmental concern. Gezi Park in Taksim is one of the green spaces which is intended to be destroyed by the municipality of Istanbul following the neoliberal policies of urbanization that constantly destroy green areas in major cities. The project to pedestrianize Taksim ${ }^{45}$ thus aims to demolish this small park in order to build a shopping mall inspired by a historical palace, by which several civil society organizations such as 'Taksim Solidarity', ${ }^{46}$ became concerned, alongside environmentalists and citizens. This attempt of the municipality provoked the occupation of the park by peaceful environmentalists starting on 28 May, so that they set up tents and protested against the destruction of Gezi Park. The occupation following this environmental and urban concern constitutes the origin of the Gezi Uprising during which citizens claimed their right firstly to the city and consequently to freedom and dignity. Throughout the occupation of the park for 18 days, activists "experienced simultaneously the peaks of ecstasy and the depths of sorrow" 47 as Gambetti puts it, since the experience of being and acting together and the experimentation of direct democracy interlaced with the violence of the police.

An atmosphere of festive resistance in order to prevent the destruction of a small park in the center of Istanbul in Taksim Square transformed into a battlefield following the closure of the park by the police. The repression of the government and the growing police violence conduced to the propagation of the movement, extending the issues against which citizens protested during the demonstrations. Besides the police violence and several offensive discourses made by the government, the blindness among mainstream media regarding the whole movement strongly bothered its participants and supporters. As a consequence of this blindness, citizens began to use social networks such as Facebook and Twitter not only to get information from Taksim Square, but also to communicate and organize. The Gezi Uprising mainly lasted for twenty days in May and June 2013 until the police violently evacuated the park on 16 June. $^{48}$ 
The Gezi Uprising, considered as a part of the Occupy movements, displays a new era in which people claim their democratic rights in Turkey. This awakening from political apathy emphasizes a democratic awareness of fundamental principles such as "equal rights and voice, accountability of each individual; respect for the dignity of people; development of the autonomy of individuals; defense of pluralism of lifestyles." 49 The physicality of people pervading the public places and claiming their rights transforms those spaces into alternative spaces of interaction and experience. Within this new collectivity, people experience the multiplicity, heterogeneity, difference and inclusion in order that new social relationships and new ways of acting and living together are created. Consequently, the 2013 Turkey Report of European Commission accentuates that "the Gezi Park protest in Istanbul and related protests across Turkey from May-June reflected the emergence of vibrant, active citizenry." 50

Moreover, those Occupy movements including Gezi, transform the nature of social and political movements by generating a new way of doing politics, as they break off the idea of a homogeneous community. Chomsky ${ }^{51}$ accentuates the understanding and learning process through participation and experience of people and he states that "the most exciting aspect of the Occupy movement is the construction of the associations, bonds, linkages and networks that are taking place all over - whether it is a collaborative kitchen or something else" 52 . Therefore, every singular orientation or experience constitutes a significant part of the collectivity that embraces an experimental active citizenship.

\section{Active citizenship}

Within the space of Occupy movements and Gezi Uprising, the presence of active citizenship constitutes a remarkable element. The notion of "active citizenship" differentiates from the concept of "citizenship" with its reference to the traditional meaning of membership of a nation state as a legal status. While the conventional form of citizenship relies on the belonging to a national community as a full membership of a community ${ }^{53}$ depends upon the citizen's passive acquirement of responsibilities and rights, the active citizenship features an "active involvement and engagement in the practices of citizenship." $" 54$ In this context, the latter involves the civic participation of the citizens in groups of civil society, independently from the 
political party organizations. The blurring of the traditional citizenship concept occurs through the recent formulations such as post national citizenship ${ }^{55}$ by moving out of the frontiers of the nation state, group-differentiated citizenship by exposing the difference-blindness of universalist approach, multicultural citizenship ${ }^{56}$ and universalist citizenship ${ }^{57}$ by expressing a global morality.

Byrony Hoskins ${ }^{58}$ analyses the active citizenship within the European Union context by which she addresses the significance of the word "participation". She defines the concept of active citizenship as "participation in civil society, community and/or political life, characterized by mutual respect and non-violence and in accordance with human rights and democracy." 59 According to her, it comprehends both the new forms (non-conventional forms such as participating in a protest event) and the traditional (conventional) forms of participation: that is to say, a range from responsible consumption to voting, in any case limited by ethical boundaries.

Therefore, the active citizenship incorporates primarily the civic engagement of individuals by developing a participatory democracy consciousness. Putnam ${ }^{60}$ argues that there exists a close relationship between active citizenship and civic engagement through which the formation of social capital takes shape in accordance with the shared values and experience. For Meehan, practicing active citizenship requires the combination of "voluntary action and experiential learning"61 while Zaff et al. proposes the concept of Active and Engaged Citizenship which identifies "an active and engaged citizen as someone who has a sense of civic duty, feeling of social connection to their community, confidence in their abilities to effect change, as well as someone who engages in civic behaviors." 62

The context of active citizenship includes equally the participation of marginalized, disadvantaged, divergent and minority groups in order to expand both the sense of togetherness and self-actualization. At the individual level, selfactualization involves a process of autonomous self-production and self-creation concerning the experiences and awareness of every individual in strong relation with the proper identities, values, interests, and skills. The individual level of active citizenship constitutes a leading point in this article since the act of Standing Man during the Gezi Uprising emerges from a very individual point of view. However, it results in a particular position where people put into practice an active citizenship experience. However, the purpose of this article is certainly not to assert that the 
Standing Man nor the standing men and women all over Turkey represent the one and only act of active citizenship. On the contrary, this act portrays an extraordinary example that reveals the capacity of one creative actor to mobilize a collective active citizenship.

The non-conventional and unorganized forms of civic and political activism were highly experienced during the Gezi Uprising. As in the case of Standing Man, it is possible to say that in that period of intense political environment, a bottom-up introduction of active citizenship emerged mostly from individual viewpoints and actions, yet the collective reproduction becomes a key process to get the voices of citizens heard. The propagation of that act all over Turkey occurred through social media. Barrett and Zani mention as non-conventional political participation both protest/demonstration and "using social networking sites on the Internet to distribute or share links which have a political content to friends and contacts." 63 Hence, the bodily and digital presence of people supporting the Standing Man action of disobedience enriches the context of active citizenship as well as civic engagement and political participation. Those enable the citizens to individually broaden their "personal empowerment and (...) sense of subjective well-being"64 and ensure the democratic structure and means in decision-making of the authorities and governments.

For that matter, the act of Standing Man appears to be "latent political participation" "65, a term by which Ekman and Amnå suggests the actions "not directly or unequivocally classified as 'political participation', but (...) [with] great significance for future political activities." 66 They determine thus the "latency" in comparison with the formal and extra-parliamentary political participation. From their perspective, such "pre-political actions" may bring about political consequences even if they do not aim at pressuring directly the authorities in power. This article aims thus to point out that both the individual and collective levels of the act of Standing Man illustrate an action grounded in personal interests in social and political issues, which reveals the performativity and active citizenship of singularities during the Gezi Uprising as it was in all the Occupy movements.

\section{The Dynamic Relation of Art and Politics: Performative Repertoire of Action}


During the Occupy movements, alternative methods of individual or collective participation and resistance revealed a performative repertoire of action within everyday life as well as an inheritance of creative resistance vocabulary. The notion of "performativity" is derived from the lectures of the linguist J.L. Austin ${ }^{67}$ on "performative utterances" in 1955 and from the work of sociologist Goffman ${ }^{68}$ on theatrical performance as a metaphor of social interactions in 1959. In this context, "performance" appears to be in between the spaces of the real and the fictional act. ${ }^{69}$ Subsequently, starting from 1966, Schechner ${ }^{70}$ develops his "performance theory" through which he acknowledges everyday life, arts, sports, business, ritual and play as performances. For him, "there is nothing inherent in an action in itself that makes it a performance or disqualifies it from being a performance" 71 , then there exists performativity in everything. Theories of performativity, which are later on reshaped by post-structuralism in philosophy and aesthetics, feminist and post-colonialist studies present an anti-authoritarian vision. All actions are performative for Butler ${ }^{72}$ who reconstitutes the notion of performativity in the process of constitution of the gender. She states that "the gender reality is performative, which means, quite simply, that it is real only to the extent that it is performed." 73

The notion of performativity in the Gezi Uprising as in other Occupy movements resides not merely in the fact that every action incorporates a performative act. Artistic creation as resistance, which refers to performance art, also embodies an experimentation of alternative methods within the movements' collective energy. During those movements, new forms of creative expression elicit a dynamic relationship between art and politics through an action of tactical intervention. Several artistic expressions realized within the Gezi Uprising reflect creativity and performativity of individuals and reveal an immediate and spontaneous nature, related to subjective action and collective energy all at once. As Göle mentions "the political significance and effectiveness [of Gezi] is rooted in its public performativity." "74 Gezi protesters appear to be "artists in action" who practice "action art" according to Yalçıntaş, who designates the creativity as the "bio-political survival strategy of intellectually disobedient protesters willing to engage in a new political discourse."75

In this respect, in those movements there exists an intertwined relationship between art and politics considering the creativity and performativity of the interventions. Rockhill states that art and politics "are differentially constituted 
sociohistorical practices"76 instead of the assumption that there exists a stable relationship or a sort of ontological separation. Within their dynamic relationship, he stresses that "various relations are constructed and dismantled in the social sphere through a series of ongoing battles." 77 In this matter, he suggests that art "might embody strategies for transformation"78 rather than an inherent political force.

With the emergence of global movements against neoliberal capitalism starting with demonstrations against the WTO in Seattle in the late nineties, art is reintroduced as a tactical action that challenges the course of global capitalism. Christian Scholl ${ }^{79}$ argues that in moments of madness, such as the exhibition of giant puppets of world leaders during the rally in Seattle, there exists an interpenetration of instrumental action and expressive articulation. Disruption and confrontation are the key features of revolutionary change as he discusses, that would transform the making of classical protest.

Within this context, it is important to consider the historical artistic movements that can also be observed in the context of global uprisings today. The avant-garde movement of the $1960 \mathrm{~s}$, the Situationist International ${ }^{80}$, organized by intellectuals and artists intended to create "situations" through which temporal ruptures were put in practice. This movement based on creating unexpected artistic situations introduces concepts such as anonymous and collective production in order to reinforce interaction. Moreover, Hakim Bey, the author of TAZ (Temporary Autonomous Zone) emphasizes the notions like spontaneity and unpredictability for tactical artistic interventions. Following that, he proposes "a guerilla operation which liberates an area (of land, of time, of imagination) and then dissolves itself to re-form elsewhere, before the State can crush it." 81 This kind of spontaneous creation of spaces and situations interrupts the normal course of things and involves a survival strategy by acknowledging the gradual transformation of the system.

"Bed-ins for peace" 82 by John Lennon and Yoko Ono in spring 1969 may be observed as a notable meeting point of performance and protest. Ono and Lennon initiated this bed-in performance during the Vietnam War to protest against war and violence and to become the voice of peace. They remained in bed dressed in white during their honeymoon and welcomed the international press into their hotel room. A more recent performance in public space is that of the Cuban artist Tania Bruguera. ${ }^{83}$ During her performance, Bruguera offered a stage and a microphone to Cuban 
citizens on Revolution Square in Havana, in order to allow them to express their views about the future. One minute of freedom of expression caused the arrest of the artist on December 30, 2014 by the Cuban authorities, so that she was held in detention in Cuba until July 2015. Furthermore, the acts of civil disobedience of "Tute Bianche" during the protests against the G8 in Genoa in $2001^{84}$ and the tactical frivolity interventions of "Pink \& Silver" during the protests against the IMF and World Bank in Prague in $2000^{85}$ are some other examples of creative nonviolent actions vis-à-vis the police force.

Within the Gezi Uprising, creativity and performativity led to a particular shift of the political action in Turkey towards a more humorous and performative repertoire of action. The new forms of expression that were mostly performed in a spontaneous way during the uprising, brought along an experience of politics as art through the carnivalesque ambience. The Standing Man has become a very substantive performative action and one of the best-known symbols of Gezi Uprising since it was more effective in terms of reproduction through the propagation on social media.

\section{Methodology}

The methodology adopted in this paper is qualitative ${ }^{86}$ in two senses: Firstly, the data is obtained from the testimony of the artist and the texts of interpreters in the mainstream and social media and the data is interpreted in a qualitative manner that emphasizes the meaning ${ }^{87}$ constructed within the experience rather than statistical data. Secondly, the process of the research relies on a qualitative basis that leads to the interpretation and understanding of practices and experiences. The meaning is perceived within the encounter between the occurrences pertaining to the research subject and their comprehension, which requires a hermeneutic approach. Hermeneutics as a process of understanding, and interpretation implies a productive attitude $^{88}$ within which the meaning is in the course of continuous becoming. As Ameigeiras stresses, "the meaning is constructed by the actor and reconstructed within the interpretation." 89

Qualitative analysis thus refers to the meeting point of the sensibility of the researcher and the experiences of the interviewee(s). Considering that there is a 
principal author of the act of Standing Man, it appears necessary to conduct a process, which mainly consists of the testimony of the artist in order to examine the meaning that he gives to his action. As the interpretive-hermeneutic and comprehensive approach would provide a better understanding of the sensible and corporal experience of the artist, a comprehensive interview ${ }^{90}$ was conducted with Erdem Gündüz in Istanbul on January 3, 2015. After the transcription and the translation of the interview, a rearrangement of the data obtained has been made in order to categorize the moments and specific experiences, and draw a path for the interpretation.

In addition to that, the data provided by the participatory observation of the author of this paper assisted in reconstructing the shared experience within the given context of the Gezi Uprising. However, the author is also bound to maintain a critical reflexivity vis-à-vis the research subject. In other words, it is critical that the author becomes aware of her prejudices, values, and emotions as well as those of the interviewee. In this regard, Bourdieu ${ }^{91}$ warns about the "biographical illusion" which may provoke an "official self-introduction". Being capable of introspection and emotional disengagement, and recognizing the affiliations and the social surface is of assistance in controlling the data analysis. It is therefore imperative to preserve a reflexive practice considering that the interviewee identifies himself by his emotions and subjectivity as well as his socially constructed identity.

Furthermore, an exploration in regard to national and international media such as BBC, Guardian, CNN, Hürriyet, Radikal and Milliyet has been made due to the fact that the affirmations of several authors indicate a significant point of reference for multiple definitions given to this act. In order to observe the propagation of the act, an analysis has been made following the headlines and the contents of the articles from June 17 and 18, 2013 in national and international media such as Hürriyet, Radikal, Milliyet, sendika.org, Cnn International and Guardian. In addition to that, since the social networks served as space for the propagation of the spontaneous participation of people to the act of the artist, an enquiry based on hashtag ethnography ${ }^{92}$ is conducted on Twitter. The latter includes a research on specific hashtags such as \#duranadam, \#standingman, \#direnduranadam and \#durankadin between June 17 and $18,2013 .{ }^{93}$ 


\section{The "Standing Man"}

Erdem Gündüz ${ }^{94}$, a Turkish performance artist and dancer, stood still for eight hours, motionless and silent in the middle of Taksim Square in Istanbul on June 17, 2013. His performative protest against police and state violence profoundly affected the participants and supporters of the Gezi Uprising due to the fact that it appeared during a particularly hopeless moment towards the end of the resistance, that is to say after the evacuation of the park by police. As he created a space of liberty in the heart of an oppressive situation, his act spread first nationwide and then worldwide through social media, taking on the hashtag \#duranadam (\#standingman) on Twitter. \#duranadam was the $6^{\text {th }}$ most shared hashtag of the Gezi Uprising, which was used more than one million times on Twitter on June 17 . On that day, while $73,6 \%$ of the tweets had duranadam hashtag, the succeeding hashtags were \#direnduranadam (resist standing man) and \#durankadin (standing woman). ${ }^{95}$ Numerous tweets with those hashtags including photos and videos demonstrate the propagation of this act all over the country.

The mainstream media reacted manifestly to this act, which spreaded widely throughout Istanbul and then Turkey via social media. Starting from Taksim Square, people occupied the public spaces all around Turkey so that the protest became an "epidemic" as it is described in Hürriyet, one of the mainstream Turkish journals on June 18, 2013. ${ }^{96}$ Some members of the Turkish parliament performed Standing Man protest in the parliament such as BDP deputies Pervin Buldan, İdris Baluken, Sebahat Tuncel, Nursel Aydoğan and Sırrı Sakık, and MHP deputy Oktay Vural during his party's press conference. ${ }^{97}$ Moreover, 22 members of the press put into practice the Standing Man act during the European Commission meeting called 'Speak Up' in Brussels on June 20, 2013. ${ }^{98}$ Even as a counter-protest to the Standing Man, 'Standing Men against the Standing Man' took the streets during which they stood still in front of standing people. ${ }^{99}$

The moment, the place, and the time of the realization of this act have a great significance given that the artist appeared in Taksim Square the day after the park was violently cleared from demonstrators by police, which terminated the community life and resistance in the park. The spirit of hope that predominated the resistance therefore came to an end and Gezi Park was closed to all public entrance. On the 
afternoon of 17 June 2013, a man in a white shirt and with a backpack suddenly appeared in Taksim Square and began to stand still and silent despite the ongoing harassment of the police, he paved the way for a space of freedom among the citizens who supported the resistance. He stood still and silent in the middle of Taksim Square for eight hours. Throughout these eight hours he conquered not only the public square, but also the public sphere on social media.

It was simple. When I got there, there was nothing to do. When I decided to stop, it wasn't like I had decided or wanted to stand. At that point, there was nothing to do. But the thing that happened was, as if I had conquered the square because I was standing. Square, occupy. Alone, but you master the square. ${ }^{100}$

Those words of the artist point out the spirit of the Occupy movements as well as the creative and unpredictable nature of performative action. Considering the fact that Erdem Gündüz, the principal auteur of this act is a dancer and performer who works on stillness and temporality, his act is also observed as performance in the sense of performance art. Various sources consider this act as a "silent performance (...) form of creative protest - endurance art as activism"101, "disproportionate creativity"102; Tunç asserts that "this time there was no word, no text, no leader in this performance. It was simple, calm, gentle, aesthetic, yet intense. This micro-seized moderate act made the whole grand political narratives look ridiculous"103. Others call it "silent protest"104, "passive resistance"105 and "civil disobedience."106 However, before the mentioned denominations in the traditional media, his act spread immediately through social networks, especially through Twitter, which provoked the propagation of the act of Standing Man first around Taksim Square, then all around Turkey and finally around the world.

As a matter of fact, through the act of Erdem Gündüz, presumed boundaries between art and politics collapsed so that standing still and silent profoundly disrupted political and police order during the course of the Gezi Uprising. Moreover, unexpected and artistic interventions such as Standing Man portray the tactical utilization of art under politically sensitive circumstances. His gesture puts forward a new way of protesting to be heard, through the spontaneous existence of his body. 
The reproduction of his act suddenly transforms a subjective experience into a collective disobedience.

\begin{abstract}
Whoever stood, did something original, since each of them had different intentions and opposed the power or fought for freedom, he/she resisted. This is the reason that each time it was original. They shared. I never said it was my performance or my protestation. (...) This incident is not an incident of a single person; it is something that affects everyone. And therefore it is something that belongs to everyone. ${ }^{107}$
\end{abstract}

On that day and the following days, his act was reproduced by other people in different ways and spaces giving rise to a collective performative action. The bodily immobile presence represents firstly a nonviolent act considering the violence executed by the police forces. Secondly, it embodies a legal and easily copyable act so that each person could put it into practice related to his/her own intentions or motivations. However, a mass action is formed by the subjective presences and motivations manifesting a nonviolent resistance beyond the spatial existence of Gezi Park.

\title{
Resisting bodies
}

As the act of Erdem Gündüz transformed into a mass action of resistance all around Turkey, incorporating both artistic and political repertoires, the collective power of resisting bodies determines a new mode of civil disobedience and redefines the meaning of active citizenship through the occupation and performative action. Hence, it becomes an "unappropriated act"108 by which the Standing Man represents the multitude of the resisting singular bodies. This singular "stand-in" of a man transmutes accordingly into a collective, intra-generational, multi-gender direct action.

The "stand-in" is defined by Gene Sharp as "the act of persistently standing and waiting at a certain place to gain an objective"109, which constitutes a method of nonviolent direct action. The well-known stand-in of "Tank Man" of China who stood in front of military tanks, carrying a simple shopping bag during the Tiananmen movement in 1989 represents this kind of nonviolent action facing an extremely 
violent and unequal situation. Erdem Gündüz also recognizes the resemblance of his act to this unpredicted stand-in of Tank Man and the Civil Rights Movement of African-Americans against segregation. Those actions indicate the strong connection of his act to the political repertoire of action along with its performative character as mentioned previously.

Everything is connected. I'm not the first person who opposes the power or injustice, and I will not be the last. Like the demonstrations of AfricanAmericans, like the man in Tiananmen Square and many others that oppose the government. I am neither the first nor the last. ${ }^{110}$

Such iconic moments of resistance and nonviolent action put forward a framework of a new form of doing, thinking, and resisting, by evoking a sense of freedom in the long term without reaching grand immediate changes. Such acts constitute recognition of resistance in other individuals. During the Civil Rights Movement, the sit-ins were held to uphold the rights of African-Americans against racial segregation and discrimination in the sixties. These were the occupations of restaurants and theatres during which the demonstrators were waiting for hours to be served in order to receive equal treatment. Likewise, the nonviolent resistance in India was constituted by a spiritual power and the nonviolent moral ideology of Gandhi's principles, such as ahimsa (nonviolence) and satyagraha (truth force) ${ }^{111}$. The latter may consist of temporary work stoppage, strikes, boycotts, non-payment of taxes, non-cooperation and civil disobedience. ${ }^{112}$

The choice of non-violence puts into practice a refusal to fight against the state on its own terms, which is violence. ${ }^{113}$ The artist therefore chooses a nonviolent action by his "stand-in" and rejects any violent situation at all, not only for himself but also on behalf of other individuals who reproduce this act of resistance. As a matter of fact, he puts an end to his protest in order to prevent men and women beside him in Taksim Square from incurring any kind of violence, while the police got ready to attack people in the square.

About two o'clock in the morning, the police were getting ready to attack, they began to put on their helmets and shields. I went a little behind, but they were still 
coming, so I took my bag and started to walk toward İstiklal. Why? Because, what I did was an act without violence. It was a peaceful one. No insult, nothing destructive. (...) If someone confronted violence, then this protest wouldn't be successful. ${ }^{114}$

As a consequence, the artist receives several prizes for his nonviolent performative action such as the "Potsdam Media International M100 Media Award" from Germany in 2013, the "Václav Havel Prize for Creative Dissent" from the Oslo Freedom Forum and the "Standing Man Prize" from Italy in 2014. In his Oslo speech, he defines himself as a citizen performing "a silent protest, an activism, a performance at the right time and the right place." 115

\section{Performative action through a small tactical gesture}

"Standing Man" contributes to the new language by implicating his silence and immobility, even though those elements seem at first to be the subject of a compromise. Since verbal and moving action against injustice are habitually considered as tools of resistance to be heard in political action, Standing Man goes beyond the ordinary and presents some sort of impediment to the government and the police force. By a reinvention of this creative and performative language in the Gezi Uprising, the solidarity and shared experience transcended the occupation of the park.

In this respect, it is important to bear in mind that the act of Standing Man occurs thanks to a simple everyday gesture: standing still. "The politics of small gestures" 116 to which Hannula refers, envisions "art as a partner in crime". He argues that "a small gesture is a political act that is either visible or embedded in works of art." 117 Once those gestures that belong to everyday experience emerge in the public sphere, they could make a difference and restructure these spheres as the act of Standing Man did. In addition to that, Citton $^{118}$ claims that the politics of gestures elicits a dynamic and unpredictable experimentation of micro-political practices. However, while Hannula suggests an idea of politicization instead of politics, which becomes a possibility to create and imagine alternatives, Citton lays emphasis on "unexpected gesture" as "a deviation, a shocking image, an ambiguous signal"119 that would trigger the dynamic for a reversal. 
Citton's approach strongly points out the political power of gestures given the fact that they reveal an immediate relation to everyday experience. The author stresses that the first gesture, which goes off unexpectedly, could awaken "hyper gestures" in social movements, as it is in the case of Standing Man. Within public spheres of Occupy movements across the world, creative subjects and anonymous artists continuously put into practice a politics of gesture. A single gesture transforms into hyper gestures that bring out a performative and emancipating energy in order to express shared or varied vulnerabilities and inequalities. The "stand-in" of the artist, on June 17, 2013 generates this sort of creative energy by a simple gesture, so that many people in Turkey and all over the world could reproduce it in several public spheres.

The artist himself describes his small and simple gesture like "eating, drinking, sitting, listening." ${ }^{120}$ However, with his stillness and silence he creates one of the iconic tactical gestures of the Gezi Uprising; he sets "the rules of the game" by which a hyper gesture engenders:

"Rule one: do not talk! Rule two: Do not move! Very simple, but since the police didn't know these rules, they did not know how to play this game. If you don't know how to play the game, it is difficult to win."121

Through this gesture of standing still and silent, a new political vocabulary emerges, not for the purpose of overthrowing all the existing systems, but rather to create pressures to break off the feeling of impuissance. It becomes a small "exemplary gesture"122, a generator of "micro-political pressure"123 without the use of violent means, which interrupts not only the exhaustion of hope but also the ordinary fluidity of everyday life in Taksim Square.

The singular "stand-in" of Standing Man transforms into a collective action through social networks and is reproduced by people with several intentions. In connection with the new society in which ephemeral, liquid ${ }^{124}$ and unpredicted action comes into prominence, this act offers a performative protestation that reflects the nature of the era of fugacity. It stands still in a world of constant movement. It owns its era as well as it is tactical so that it appears all of a sudden and then it disappears until somebody else suddenly appears somewhere else. It becomes a network of 
bodies of women and men silently standing still. ${ }^{125}$ At last, it simultaneously contradicts and appropriates the principles of existence of today's reality as it evolves into a collective tactical intervention, both artistically and politically.

\section{Conclusion}

This paper draws attention to the recreation of active citizenship by virtue of a singular performative act that generates collective action. The "stand-in" of Standing Man and its reproduction throughout Turkey and the world point out a very significant use of unconventional forms of resistance and participation to social conflicts during Occupy movements. That act as a singular example that reflects the citizens' engagement and participation in those movements reveals a considerable influence and contribution of creative interventions to the political repertoire of action. The regenerative impact of this performative act occurs through the construction of autonomous spaces and the subjective experiencing so that it questions the conventional political action. Consequently, it enounces a different kind of relationship with politics. The participation of autonomous actors appears to develop in a horizontal non-institutionalized space of politics to the extent that the emphasis is tended to be on personal resistance against whatsoever representing interference on human rights. Therefore, one self-initiated resistance generates a social connection even though it creates at first an autonomous space of tactical performative intervention.

Each performed "stand-in" following the initial Standing Man, manifests a spontaneous and informal statement of self-perspective and experience by which an active citizenship and experiment of a new kind of interaction of singularities come into existence. These non-organized collectivities engendered by means of social networks eventually have noteworthy impact on political space by nourishing the understanding and experiential learning processes, even while they remain as ephemeral performative actions. Moreover, the reproducibility of Standing Man owes to its proposition of a creative protest by means of a small everyday gesture, which is standing still and silent. The transformation of the singular spontaneous act of nonviolent resistance into a collective reconstitution of subversive situations brings out the political power of a simple gesture by becoming a hyper gesture. Collective 
reproduction of the "stand-in" of Standing Man conquers both the space of artistic and political repertoires of action by rejuvenating the strategies for transformation.

In the light of latest events in Turkey, that is to say coup attempt on July 15, $2016^{126}$, the concept of active citizenship extends even further. The people going out against heavily armed soldiers in order to block the coup d'état opens up a new kind of political engagement. Those who went out that night were presumably the supporters of the AKP government and the president Erdoğan, following his call on CNNTürk to go out and resist against the military forces. The sound of muezzins from the mosques all over Turkey accompanied the call of their leader Erdoğan, which created an unexpected and brave, yet semi-institutionalized resistance. In other words, contrary to the Gezi Uprising, it appears to be a hierarchical social movement organized around a leadership. Nonetheless, it cannot be overlooked the fact that a different kind of relationship with politics has emerged for those "democracy watchers"127 since throughout the religiously oriented political tradition in Turkey people do not have much experience in unconventional forms of political action. It appears that this time it wasn't enough just to vote for democracy as Erdoğan had previously stated, but rather to take the streets protecting the "will of the people."128

The mobilization of the people occurred mainly by means of the political power so that it cannot be presented as a self-initiated and spontaneous resistance, however it represents an intense subjective experience throughout the practice of taking the streets. Therefore, it develops the "savoir faire" of resistance among those people and a new kind of active citizenship experience. Nevertheless, it is still an ongoing process and it is also a brand-new research area to explore more, considering the encounter between the dominant term utilized during this resistance, the "democracy" and the declaration of the "state of emergency" by the Turkish state.

\section{Disclosure Statement}

No potential conflict of interest was reported by the author.

\section{Notes}


1. See Tilly, La France conteste de 1600 à nos jours for his notion of "repertoire of contention," which refers to a set of shared means (tools or action) in a protest movement.

2. See Touraine, La Voix et le Regard; Melucci, L'invenzione del presente: Movimenti sociali nelle societa complesse and Offe, "New Social Movements: Challenging the Boundaries of Institutional Politics."

3. See Neveu, Sociologie des Mouvements Sociaux.

4. Touraine, "An Introduction to the Study of Social Movements," 778.

5. Ibid., 780.

6. Melucci, "A Strange Kind of Newness: What's New in New Social Movements?," 114.

7. Ibid.

8. See Melucci, "The Symbolic Challenge of Contemporary Movements" and "A Strange Kind of Newness: What's New in New Social Movements?"

9. See Offe, "New Social Movements: Challenging the Boundaries of Institutional Politics." "Political paradigm" is a notion which is borrowed and redefined by Offe from J.Raschke ("Politik und Wertwandel in den westlichen Demokratien," Am Politik und Zeitgeschichte. no. :6 (1980): 23-45.)

10. Ibid., 829 .

11. Ibid., 826, 832 .

12. Ibid., 831 .

13. See Alvarez, "Beyond NGO-ization? Reflections from Latin America."

14. See Arundhati Roy's speech on Democracy Now:

https://www.democracynow.org/2004/8/23/public power in the age of

15. See Jad, "The NGOisation of Arab Women's Movements," Arundhati Roy's speech on Democracy Now; Alvarez, "Beyond NGO-ization? Reflections from Latin America" and Jad, "NGOs: Between Buzzwords and Social Movements."

16. See Arundhati Roy's speech on Democracy Now.

17. Ibid.

18. Alvarez, "Beyond NGO-ization? Reflections from Latin America," 176.

19. Jad, "NGOs: Between Buzzwords and Social Movements," 627.

20. See Wieviorka, "After New Social Movements."

21. See Pleyers, Alter-Globalization: Becoming Actors in the Global Age.

22. Ibid. and See Pleyers, "The Global Justice Movement."

23. Wieviorka, "After New Social Movements," 11.

24. See Glasius and Pleyers, "The Global Moment of 2011: Democracy, social Justice and Dignity."

25. Touraine, Le Nouveau Siècle Politique, 11.

26. Ibid., 181.

27. Hardt and Negri, Declaration, 4.

28. See Ogien and Laugier. Le Principe Démocratie : Enquête sur les Nouvelles Formes du Politique and Castells, Khosrokhovar and Touraine, "L'unité des Grandes

Contestations Contemporaines."

29. Hardt and Negri, Declaration, 4-5.

30. Glasius and Pleyers, "The Global Moment of 2011: Democracy, social Justice and Dignity," 554.

31. See Wieviorka, "After New Social Movements."

32. Castells, Networks of Outrage and Hope: Social Movements in the Internet Age, 4.

33. See Castells, Khosrokhovar, and Touraine. "L'unité des Grandes Contestations Contemporaines."

34. See Juris, "Reflections on \#Occupy Everywhere."

35. See Castells, Networks of Outrage and Hope: Social Movements in the Internet Age. 
36. Juris, "Reflections on \#Occupy Everywhere," 260.

37. See Park, Lim and Park, "Comparing Twitter and YouTube Networks in Information Diffusion."

38. See Tuğal, "Resistance Everywhere: The Gezi Revolt in Global Perspective"; Pleyers and Capitaine, ed. Mouvements Sociaux: Quand le Sujet Devient Acteur and Özkırıml1, ed. The Making of a Protest Movement in Turkey: \#occupygezi.

39. See Yörük and Yüksel, "Class and Politics in Turkey's Gezi Protests."

40. See Özatalay, "Gezi Direnişi: Antikapitalist mi, Alter-Kapitalist mi?"

41. Ibid.

42. See Yörük and Yüksel, "Class and Politics in Turkey’s Gezi Protests."

43. See Tuğal, "Resistance Everywhere: The Gezi Revolt in Global Perspective."

44. Derman, "Un Stand-in Créateur des Contre-publics: La Protestation Performative de l'Homme Debout."

45. The Municipality of Istanbul announces the Taksim pedestrianization project in 2007, though the construction work begins October 31, 2012.

46. Taksim Dayanışması (Taksim Solidarity) includes more than 100 NGOs and associations: http://taksimdayanisma.org/?lang=en

47. Gambetti, "Occupy Gezi as the Politics of the Body," 90.

48. See Derman, "Un Stand-in Créateur des Contre-publics: La Protestation Performative de l'Homme Debout."

49. Ogien and Laugier. Le Principe Démocratie : Enquête sur les Nouvelles Formes $d u$ Politique, 7.

50. European Commission Turkey 2013 Progress Report, p.11. http://ec.europa.eu/enlargement/pdf/key documents/2013/package/brochures/turkey 2 013.pdf

51. See Chomsky, Occupy.

52. Ibid., 45 .

53. See Marshall, Citizenship and Social Class: and other Essays.

54. Mansouri and Kirpitchenko, "Practices of Active Citizenship among Migrant Youth: Beyond Conventionalities," 311 and see Turner, "Outline of a Theory of Citizenship."

55. See Soysal, Limits of Citizenship: Migrants and Postnational Membership in Europe.

56. See Kymlicka, Multicultural Citizenship: A Liberal Theory of Minority Rights.

57. See Linklater, Critical Theory and World Politics: Citizenship, Sovereignty and Humanity.

58. See Hoskins, "Draft Framework for Indicators on Active Citizenship."

59. Ibid. and see Mascherini and Hoskins, "The Characterization of Active Citizenship in Europe."

60. See Putnam, Bowling Alone: The Collapse and Revival of American Community.

61. Meehan, "Active citizenship: For integrating the immigrants," 115.

62. Zaff et al., "Active and Engaged Citizenship: Multi-group and Longitudinal Factorial Analysis of an Integrated Construct of Civic Engagement," 737.

63. Barrett and Zani, "Political and Civic Engagement: Theoretical Understandings, Evidence and Policies," 5.

64. Ibid., 8-9.

65. See Ekman and Amnå, "Political Participation and Civic Engagement: Towards a New Typology."

66. Ibid., 287.

67. See Austin, How to do things with words : "to say something is to do something."

68. See Goffman, The Presentation of Self in Everyday Life.

69. See Spielmann, "L'événement-spectacle: Pertinence du Concept et de la Théorie de la Performance."

70. See Schechner, Performance Theory and Schechner, Performance Studies: An Introduction. 
71. Schechner, Performance Studies: An Introduction, 38.

72. See Butler, Gender Trouble: feminism and the subversion of identity.

73. Butler cited in Schechner, Performance Studies: An Introduction, 151.

74. Göle, "Gezi - Anatomy of a Public Square," 12.

75. Yalçıntaş, "Intellectual Disobedience in Turkey," 19. The concept of "action art" mentioned by Yalçıntaş in his text is taken from Pavlina Morganova (2014) who uses the term as a form of expression under the political suppression of Cold War.

76. Rockhill, Radical History \& The Politics of Art, 225.

77. Ibid., 226.

78. Ibid.

79. See Scholl, "Bakunin's poor cousins: Engaging art for tactical interventions."

80. See Knabb, ed. Situationist International Anthology.

81. See Bey, T.A.Z. Temporary Autonomous Zone: Ontological anarchy, Poetic Terrorism.

82. See https://www.youtube.com/watch? $\mathrm{v}=\mathrm{mRjijiOV003Q}$

83. See http://www.taniabruguera.com and http://www.latimes.com/entertainment/arts/miranda/la-et-cam-artist-tania-brugueradetained-cuba-20141231-column.html

84. See http://www.repubblica.it/online/politica/gottosei/bianche/bianche.html

85. See https://www.youtube.com/watch? $\mathrm{v}=\mathrm{xgfjgFqkCao}$ and https://www.youtube.com/watch?v=GIVvBF 7JDo

86. See Paillé and Mucchielli, L'Analyse Qualitative en Sciences Humaines et Sociales.

87. Ibid, 61: "The meaning can be defined as the human experience (real or imagined), which may be related to an utterance (word or set of words) that allows the understanding."

88. See Gadamer, Vérité et Méthode. Les Grandes Lignes d'une Herméneutique Philosophique.

89. Ameigeiras, "L'herméneutique dans l'approche ethnographique. Du labyrinthe de la compréhension au défi de l'interprétation," 39-40.

90. See Kaufmann, L'entretien compréhensif.

91. See Bourdieu, "L'illusion biographique."

92. See Bonilla and Rosa, "\#Ferguson: Digital Protest, Hashtag Ethnography, and the Racial Politics of Social Media in the United States."

93, An example of the formula used for the research: \#duranadam since: 2013-06-17 until 3013-06-18 :) include: retweets.

94. http://www.erdemgunduz.org (artist's website) and see https://www.youtube.com/watch?v=hQ1vRjJHWZE video on You Tube for the beginning of the protest of Standing Man.

95, See Banko and Babaoğlan, Gezi Parkı Sürecinde Dijital Vatandaşın Etkisi ; "The Gezi Park Incident Evaluation Report," SiegeArts, https://siegearts.com/reports/tr/geziparki/index en.php ; "Gezi Olaylar1 Sosyal Medya Analizi," July 8, 2013, http://insightradar.com/tr/gezi-olaylari-sosyal-medya-analizi/ and "Gezi Direnişinin Ekşi Sözlükteki Yansımaları", July 23, 2013, https://ssgpp.wordpress.com/2013/07/23/gezi-direnisinin-eksi-sozlukteki-yansimalari/

96. Yıldırım and Ural, "Duran Adam Salgını" [The Epidemic of Standing Man], Hürriyet, June 18, 2013. http://www.hurriyet.com.tr/duran-adam-salgini-23530185; see

“Toma'ya karşı Duran Adam,” Radikal, June 19, 2013, http://www.radikal.com.tr/turkiye/tomaya-karsi-duran-adam-1138271// "Herkes Duran Adamı Konuşuyor" [Everybody Talks About Standing Man], Milliyet, June 18, 2013, http://www.milliyet.com.tr/herkes-duran-adam-i-konusuyor/gundem/detay/1724339/default.htm ; Tüysüz, Penhaul and Lee, "Hundreds of Turks emulate 'Standing Man' in protest," CNN, June 19, 2013. http://edition.cnn.com/2013/06/18/world/europe/turkey-protests/ and 140journos tweet, June 18, 2013, 5:26 a.m. ; https://twitter.com/140journos/status/346816032985473025; 
"Duran İstanbul... Taksim'de Gece boyu Durma Eylemi” [Standing Istanbul...

Standing Act in Taksim through the Night], http://www.radikal.com.tr/turkiye/duranistanbul-taksimde-gece-boyu-durma-eylemi-1138079/. See also note 104,105 and 125.

97. "Meclis'te Duran Adam Eylemi," Ntv, June 18, 2013, http://www.ntv.com.tr/turkiye/mecliste-duran-adam-eylemi,qZzA3rE0-0ytKplnC2RJA? ref=infinite and "MHP Grup Başkanvekili Vural'ın Basın Toplantısı," MeclisHaber, June 19, 2013, http://www.meclishaber.gov.tr/develop/owa/haber_portal.aciklama?p1=125673.

98. “AB Toplantısında ‘Duran Adam' Eylemi,” Radikal, June 20, 2013, http://www.radikal.com.tr/dunya/ab-toplantisinda-duran-adam-eylemi-1138467/

99. "Duran Adam'in Antitezi Sokağa Çıktı!", Radikal, June 19, 2013, http://www.radikal.com.tr/turkiye/duran-adamin-antitezi-sokaga-cikti-1138289/

100. Interview with Erdem Gündüz, Istanbul, 03.01.2015.

101. Roffino, "How One Turkish Artist's Silent Performance kept the Protests Alive."

102. Güllü, "Duran Adam: Post-Avangard bir Direniş Estetiğine Doğru mu?"

103. Tunç, "\#Standing Man: Aesthetics of Nonviolent Resistance."

104. BBC News, “Turkey's 'Standing Man' Silent Protest Spreads,” June 18, 2013. http://www.bbc.com/news/world-europe-22962526

105. Democracy Now, "Defiant Turkish Demonstartors 'Finding New Ways to Protest' in face of Relentless State Crackdown," June 19, 2013.

http://www.democracynow.org/2013/6/19/defiant_turkish_demonstrators_finding_new _ways and Seymour, "Turkey's 'Standing Man' Shows How Passive Resistance can Shake a State." Guardian, June 18, 2013. http://www.theguardian.com/commentisfree/2013/jun/18/turkey-standing-man

106. Hürriyet Daily News, "Standing Man Inspires a New Type of Civil Disobedience in Turkey," June 18, 2013. http://www.hurriyetdailynews.com/standing-man-inspires-anew-type-of-civil-disobedience-in-turkey.aspx? pageID $=238 \& n I D=48999 \& N e w s C a t I D=339$

107. Interview with Erdem Gündüz, Istanbul, 03.01.2015.

108. Ibid.

109. Sharp, Sharp's Dictionary of Power and Struggle: Language of Civil Resistance in Conflicts, 282.

110. Interview with Erdem Gündüz, Istanbul, 03.01.2015.

111. See Gandhi, Non-violence in Peace \& War Vol.I.

112. See Sharp, "The Meanings of non-violence: a typology (revised)."

113. See Hardman, "Towards a History of Non-violent Resistance."

114. Interview with Erdem Gündüz, Istanbul, 03.01.2015.

115. Gündüz, Speech in Oslo Freedom Forum, https://www.youtube.com/watch?v=xlkW1qGE488.

116. See Hannula, The Politics of Small Gestures: Chances and Challenges for Contemporary Art.

117. Ibid., 7.

118. See Citton, Renverser l'insoutenable.

119. Ibid., 144.

120. Interview with Erdem Gündüz, Istanbul, 03.01.2015.

121. Ibid.

122. See Scholl, "Bakunin's poor cousins: Engaging art for tactical interventions."

123. See Citton, Renverser l'insoutenable.

124. See Bauman, La vie liquide.

125. See Sendika.org, "Direnişin Yeni Simgesi \#duranadam ve \#durankadınlar çoğalıyor" [The New Symbol of Resistance \#standingmen and \#standingwomen Multiply], June 18, 2013, http://sendika10.org/2013/06/direnisin-yeni-simgesi-duranadam/; The Guardian, "Turkey's 'Standing People' Protest spreads amid Erdoğan's crackdown," 
June 18, 2013, http://www.theguardian.com/world/2013/jun/18/turkey-taksimstanding-protests-erdogan and Independent, “Turkey's 'Standing Man' Captured Attention, but Protest doesn't Stand Still - it forms Assemblies," June 25, 2013, http://www.independent.co.uk/voices/comment/turkeys-standing-man-capturedattention-but-protest-doesnt-stand-still-it-forms-assemblies-8672456.html

126. See Gambetti, "Failed Coup Attempt in Turkey: The Victory of Democracy," July 18, 2016, https://www.opendemocracy.net/zeynep-gambetti/failed-coup-attempt-in-turkeyvictory-of-democracy

127. See the official site of Presidency of the Republic of Turkey, "National Will is the Strongest Antidote to Coup," July 22, 2016, https://www.tccb.gov.tr/en/news/542/49722/national-will-is-the-strongest-antidote-tocoup.html and "Tekbir Eşliğinde Demokrasi Nöbeti” [Democracy Watch accompanied with Allahuekber], Cumhuriyet, July 16, 2016, http://www.cumhuriyet.com.tr/haber/turkiye/568682/Tekbir_esliginde demokrasi n obeti... Meydanlar ayakta.html

128. See Çubukçu, "It's Will of the Turkish People, Erdogan says. But which people?", The Guardian, July 26, 2016, https://www.theguardian.com/commentisfree/2016/jul/26/turkish-people-erdogandemocracy

\section{Bibliography}

Alvarez, Sonia E. "Beyond NGO-ization? Reflections from Latin America". Development, 52:2 (2009): 175-184.

Ameigeiras, Aldo. "L'herméneutique dans L'approche Ethnographique. Du Labyrinthe de la Compréhension au Défi de l'Interprétation" [Hermeneutics in Ethnographic Approach. From the Labyrinth of Comprehension to the Challenge of Interpretation]. Recherches Qualitatives, 28:1 (2009): 37-52.

http://www.recherchequalitative.qc.ca/documents/files/revue/edition reguliere/numero28(1)/numero complet 2 $\underline{8(1) . p d f}$

Austin, John Langshaw. How to Do Things with Words. Oxford : Clarendon Press, 1962.

Banko, Meltem and Ali Rıza Babaoğlan, Gezi Parkı Sürecinde Dijital Vatandassın Etkisi [The Impact of Digital Citizen during Gezi Park]. 2013.

Barrett, Martyn and Bruna Zani. "Political and Civic Engagement: Theoretical Understandings, Evidence and Policies", In Political and Civic Engagement: Multidisciplinary Perspectives. New York: Routledge, 2015.

Bauman, Zygmunt. La Vie Liquide [Liquid Life]. Paris : Arthème Fayard, [2005] 2013.

Bey, Hakim. T.A.Z. Temporary Autonomous Zone: Ontological Anarchy, Poetic Terrorism. New York: Autonomedia, 1985.

Bonilla and Rosa, "\#Ferguson: Digital Protest, Hashtag Ethnography, and the Racial Politics of Social Media in the United States", American Ethnologist, 42 (1): 2015, 4-17.

Bourdieu, Pierre. "L'illusion Biographique" [Biographical Illusion]. Actes de la Recherche en Sciences Sociales, Vol: 62-63 (1986): 69-72.

Bryony, Hoskins. "Draft Framework for Indicators on Active Citizenship." developped by CRELL research network "Active Citizenship for Democracy", 2006. http://citeseerx.ist.psu.edu/viewdoc/download?doi=10.1.1.132.1723\&rep=rep1\&type=pdf

Butler, Judith. Gender Trouble: Feminism and the Subversion of Identity. New York: Routledge, 1990.

Capitaine, Brieg and Geoffrey Pleyers, ed. Mouvements Sociaux: Quand le Sujet Devient Acteur [Social Movements: When the Subject Becomes Actor]. Paris: FMSH, 2016. 
Castells, Manuel. Networks of Outrage and Hope: Social Movements in the Internet Age. Cambridge: Polity, 2012.

Castells, Manuel, Farhad Khosrokhovar, and Alain Touraine. "L'unité des Grandes Contestations Contemporaines" [Unity of Grand Contemporary Contestations]. Socio, no: 2 (2013): 139-167.

Chomsky, Noam. Occupy. London: Penguin Books, 2012.

Citton, Yves. Renverser l'Insoutenable [Overturn the Unsustainable]. Paris: Seuil, 2012.

Çubukçu, Ayça. "It's Will of the Turkish People, Erdogan Says. But Which People?", The Guardian, July 26, 2016, https://www.theguardian.com/commentisfree/2016/jul/26/turkish-people-erdogandemocracy

Derman, Özge. "Un Stand-in Créateur des Contre-publics: La Protestation Performative de l'Homme Debout" [A Stand-in Creator of Counter-publics: the Performative Protestation of Standing Man.] MA diss., Galatasaray University, 2015.

Ekman, Joakim and Erik Amnå. "Political Participation and Civic Engagement: Towards a New Typology." Human Affairs 22 (2012), 283-300.

Gadamer, Hans-Georg. Vérité et Méthode. Les Grandes Lignes d'une Herméneutique Philosophique [Truth and Method. The Outlines of a Philosophic Hermeneutics]. Paris: Seuil, 1996.

Gambetti, Zeynep. "Occupy Gezi as the Politics of the Body" In The Making of a Protest Movement in Turkey: \#occupygezi, edited by Umut Özkırımlı, 89-102. London: Palgrave, 2014.

Gambetti, Zeynep. "Failed Coup Attempt in Turkey: The Victory of Democracy", Open Democracy / ISA RC-47: Open Movements, July 18, 2016, https://www.opendemocracy.net/zeynep-gambetti/failed-coup-attempt-in-turkey-victoryof-democracy

Gandhi, Mahatma. Non-violence in Peace \& War Vol.I. Ahmedabad: Narajivan Publishing House, 1942.

Glasius, Marlius and Geoffrey Pleyers. "The Global Moment of 2011: Democracy, Social Justice and Dignity" Development and Change 44:3 (2013): 547-567.

Goffman, Erving. The Presentation of Self in Everyday Life. New York: Anchor Books, 1959.

Göle, Nilüfer. "Gezi - Anatomy of a Public Square.” Insight Turkey 15, no: 3 (2013): 7-14.

Güllü, Firat. "Duran Adam: Post-Avangard bir Direniş Estetiğine Doğru mu?" [Standing Man: To an Aesthetics of Postavangard Resistance?] Mimesis, June 21, 2013. http://mimesis-dergi.org/2013/06/duran-adam-post-avangard-bir-direnis-estetigine-dogru$\underline{\mathrm{mu} /}$

Gündüz, Erdem. Speech in Oslo Freedom Forum, 2014. Accessed Apr. 25, 2016. https://www.youtube.com/watch?v=xlkW1qGE488.

Hannula, Mika. The Politics of Small Gestures: Chances and Challenges for Contemporary Art. Istanbul: art-ist, 2006.

Hardman, David. "Towards a History of Non-violent Resistance" Economic\&Political Weekly 48, no: 23 (2013): 41-48.

Hardt, Michael and Antonio Negri. Declaration. New York: Argo, 2012.

Jad, Islah. "The NGOisation of Arab Women's Movements" ID Bulletin 35:4 (2004): 34-42.

Jad, Islah. "NGOs: Between Buzzwords and Social Movements" Development in Practice 17:4/5 (2007): 622-629.

Juris, Jeffrey S. "Reflections on \#Occupy Everywhere: Social Media, Public Space, and Emerging Logics of Aggregation". American Ethnologist, 39:2 (2012): 259-279.

Kaufmann, Jean-Claude. L'entretien Compréhensif [Comprehensive Interview]. Paris : Armand Colin, 2011.

Knabb, Ken, ed. Situationist International Anthology. California: Bureau of Public Secrets, 2006. 
Kymlicka, Will. Multicultural Citizenship: A Liberal Theory of Minority Rights. Oxford: Oxford University Press, 1996.

Linklater, Andrew. Critical Theory and World Politics: Citizenship, Sovereignty and Humanity. London: Routledge, 2007.

Mansouri, Fethi and Liudmila Kirpitchenko. "Practices of Active Citizenship among Migrant Youth: Beyond Conventionalities". Social Identities, 22:3 (2016), 307-323.

Marshall, Thomas Humphrey. Citizenship and Social Class: and other Essays. Cambridge: University Press, 1950.

Mascherini, Massimiliano and Hoskins Bryony. "The Characterization of Active Citizenship in Europe", 2009. http://ec.europa.eu/eurostat/documents/1001617/4398416/S11P2-THECHARACTERIZATION-OF-ACTIVE-MASCHERINI-HOSKINS.pdf

Meehan, Elisabeth. "Active Citizenship: For Integrating the Immigrants." In Active Citizenship: What Could It Achieve and How?, edited by Bernard Crick and Andrew Lockyer, 112-128. Edinburgh: Edinburgh University Press, 2010.

Melucci, Alberto. L'invenzione del Presente: Movimenti Sociali nelle Societa Complesse [Invention of the Present: Social Movements in Complex Societies]. Bologna: Il Mulino, 1982.

Melucci, Alberto. "The Symbolic Challenge of Contemporary Movements." Social Research 52, no: 4 (winter 1985): 789-816.

Melucci, Alberto. "A Strange Kind of Newness: What's New in New Social Movements?", In New Social Movements: From Ideology to Identity, edited by Enrique Larana et al., 101130. Philadelphia: Temple University Press, 1994.

Neveu, Erik. Sociologie des Mouvements Sociaux [Sociology of Social Movements]. Paris: Découverte, 1996.

Ogien, Albert and Sandra Laugier. Le Principe Démocratie: Enquête sur les Nouvelles Formes du Politique [The Principle of Democracy: Inquiry on the New Forms of Politics]. Paris: Découverte, 2014.

Offe, Claus. "New Social Movements: Challenging the Boundaries of Institutional Politics." Social Research 52, no: 4 (winter 1985): 817-868.

Özatalay, Cem. "Gezi Direnişi: Antikapitalist mi, Alter-Kapitalist mi?" [Gezi Resistance: Anticapitalist or Alter-Capitalist?], In Gezi ve Sosyoloji: Nesneyle Yüzleşmek, Nesneyi Kurmak [Gezi and Sociology: Facing the Object, Building the Object], edited by Öğütle, Vefa Saygın and Emrah Göker, 170-185. Istanbul: Ayrınt, 2014.

Özkırımlı, Umut, ed. The Making of a Protest Movement in Turkey: \#occupygezi. London: Palgrave, 2014.

Paillé, Pierre and Alex Mucchielli. L'Analyse Qualitative en Sciences Humaines et Sociales [Qualitative Analysis in Human and Social Sciences]. $3^{\text {rd }}$ ed. Paris: Armand Colin, 2012.

Park, Se Jung, Yon Soo Lim and Han Woo Park, "Comparing Twitter and YouTube Networks in Information Diffusion: The Case of the 'Occupy Wall Street' Movement." Technological Forecasting \& Social Change 95 (2015): 208-217.

Pichardo, Nelson A. "New Social Movements: A Critical Review." Annual Review of Sociology 23 (1997): 411-430.

Pleyers, Geoffrey. Alter-Globalization: Becoming Actors in the Global Age. Cambridge: Polity Press, 2010.

Pleyers, Geoffrey. "The Global Justice Movement." Globality Studies Journal, 19 (2010): 114.

Putnam, Robert David. Bowling Alone: The Collapse and Revival of American Community. New York: Simon\&Schuster, 2000.

Rockhill, Gabriel. Radical History \& The Politics of Art. New York: Columbia University Press, 2014. 
Roffino, Sara. "How One Turkish Artist's Silent Performance Kept the Protests Alive." Blouinartinfo, June 20, 2013. http://www.blouinartinfo.com/news/story/919754/how-oneturkish-artists-silent-performance-kept-the-protests\#

Roy, Arundhati. "Public Power in the Age of Empire: Arundhati Roy on War, Resistance and the Presidency." Democracy Now, August 23, 2004.

https://www.democracynow.org/2004/8/23/public power in the age of

Schechner, Richard. Performance Theory. New York: Routledge, 1988.

Schechner, Richard. Performance Studies: An Introduction, New York: Routledge, 2002.

Scholl, Christian. "Bakunin's Poor Cousins: Engaging Art for Tactical Interventions." Thamyris/Intersection, no: 21 (2010): 157-178.

Seymour, Richard. "Turkey's 'Standing Man' Shows How Passive Resistance can Shake a State." Guardian, June 18, 2013. http://www.theguardian.com/commentisfree/2013/jun/18/turkey-standing-man

Sharp, Gene. "The Meanings of Non-Violence: A Typology (Revised)." Conflict Resolution 3, no: 1 (1959) : 41-64.

Sharp, Gene. Sharp's Dictionary of Power and Struggle: Language of Civil Resistance in Conflicts. New York: Oxford University Press, 2012.

Soysal, Yasemin Nuhoglu. Limits of Citizenship: Migrants and Postnational Membership in Europe. Chicago: University of Chicago Press, 1994.

Spielmann, Guy. "L'Evénement-spectacle: Pertinence du Concept et de la Théorie de la Performance" [The Event-spectacle: Pertinence of the Concept and Theory of Performance]. Communications, no: 92 (2013): 193-204.

Tilly, Charles. La France Conteste de 1600 à Nos Jours [The Contentious France]. Paris: Fayard, 1986.

Touraine, Alain. Production de la Société [The Self-Production of Society]. Paris, Seuil, 1973.

Touraine, Alain. La Voix et le Regard [The Voice and the Eye]. Paris, Seuil, 1978.

Touraine, Alain. "An Introduction to the Study of Social Movements." Social Research 52, no: 4 (winter 1985): 749-787.

Touraine, Alain. Le Nouveau Siècle Politique. Paris: Seuil, 2016.

Tuğal, Cihan. "Resistance Everywhere: The Gezi Revolt in Global Perspective." New Perspectives on Turkey 49 (2013): 157-172.

Tunç, Asl1. "\#Standing Man: Aesthetics of Nonviolent Resistance." Mediacommons, Mar. 6, 2014. http://mediacommons.futureofthebook.org/imr/2014/03/06/standing-man-aestheticsnonviolent-resistance

Turner, Bryan Stanley. "Outline of a Theory of Citizenship." Sociology 24, no: 2 (1990): 189-217.

Tüysüz, Gül, Karl Penhaul and Ian Lee, "Hundreds of Turks Emulate 'Standing Man' in Protest", CNN, June 19, 2013. http://edition.cnn.com/2013/06/18/world/europe/turkeyprotests/

Wieviorka, Michel. “After New Social Movements" Social Movement Studies 4:1 (2005): 119.

Yalçıntaş, Altuğ. "Intellectual Disobedience in Turkey" In Creativity and Humour in Occupy Movements: Intellectual Disobedience in Turkey and Beyond, edited by Altuğ Yalçıntaş, 6-29, New York: Palgrave, 2015.

Yıldırım, Hasan and Ozan Ural. "Duran Adam Salgını" [The Epidemic of Standing Man], Hürriyet, June 18, 2013. http://www.hurriyet.com.tr/duran-adam-salgini-23530185

Young, Iris Marion. "Polity and Group Difference: A Critique of the Ideal of Universal Citizenship." Ethics 99, no: 2 (1989): 250-274.

Yörük, Erdem and Murat Yüksel. "Class and Politics in Turkey's Gezi Protests". New Left Review 89 (2014), 103-123. https://newleftreview.org/II/89/erdem-yoruk-murat-yukselclass-and-politics-in-turkey-s-gezi-protests 
Zaff, Jonathan, Michelle Boyd, Yibing Li, Jacqueline V. Lerner and Richard M. Lerner. "Active and Engaged Citizenship: Multi-group and Longitudinal Factorial Analysis of an Integrated Construct of Civic Engagement." Journal of Youth and Adolescence 39 (2010): 736-750. 